\title{
Applying interprofessional simulation to improve knowledge, attitude and practice in hospital- acquired infection control among health professionals
}

T. Saraswathy ${ }^{1,2}$, S. Nalliah³ , A. M Rosliza ${ }^{4}$, S Ramasamy ${ }^{5}$, K. Jalina $^{6}$, Hayati Kadir Shahar ${ }^{4,7}$ and S. Amin-Nordin ${ }^{\text {* }}$

\begin{abstract}
Background: This study aimed at determining the effectiveness of an innovative approach using interprofessional simulation scenarios (IPSS) in improving knowledge, attitude, and practice (KAP) of hospital-acquired infection control (HAIC) among health professionals.

Methods: The interventional study was conducted in a teaching hospital in Malaysia. Purposive sampling was used to recruit participants from surgical, intensive care, and other units. Thirty-six health professionals in the experimental and forty in the control group completed the study. All subjects participated in an interactive lecture and demonstrated four IPSS on HAIC i.e. (i) taking blood specimen (ii) bedsore dressing (iii) collecting sputum for acid-fast bacilli and (iv) intermittent bladder catheterization. Each team consisted of a doctor and a nurse. A selfadministered questionnaire on KAP on HAIC was completed by respondents during the pre-, immediately and, post-intervention. An independent t-test was conducted to measure the significance between the experimental and control group.
\end{abstract}

Results: The mean scores for KAP among the experimental group increased following the intervention. Significant differences in scores were seen between the two groups post-intervention $(p<0.05)$. Overall, using the four procedures as surrogates, the interprofessional learning approach in HAIC intervention showed improvement among the participants in the experimental group following structured instructions. The IPSS approach in HAIC clearly shows its relevance in improving learning outcomes.

Conclusions: Well-designed interprofessional simulated scenarios can be effective in skills training in improving KAP in HAIC among health professionals.

Keywords: Interprofessional, Simulation, Scenarios, Infection control, Health professionals

\footnotetext{
* Correspondence: syafinaz@upm.edu.my

'Department of Medical Microbiology, Faculty of Medicine and Health

Sciences, Universiti Putra Malaysia, Serdang, Selangor, Malaysia

Full list of author information is available at the end of the article
}

(c) The Author(s). 2021 Open Access This article is licensed under a Creative Commons Attribution 4.0 International License, which permits use, sharing, adaptation, distribution and reproduction in any medium or format, as long as you give appropriate credit to the original author(s) and the source, provide a link to the Creative Commons licence, and indicate if changes were made. The images or other third party material in this article are included in the article's Creative Commons licence, unless indicated otherwise in a credit line to the material. If material is not included in the article's Creative Commons licence and your intended use is not permitted by statutory regulation or exceeds the permitted use, you will need to obtain permission directly from the copyright holder. To view a copy of this licence, visit http://creativecommons.org/licenses/by/4.0/. The Creative Commons Public Domain Dedication waiver (http://creativecommons.org/publicdomain/zero/1.0/) applies to the data made available in this article, unless otherwise stated in a credit line to the data. 


\section{Background}

The 1999 Report 'To err is human' by the Institute of Medicine (IOM) upheld that patient safety is mandatory in clinical practice [1]. Interprofessional learning (IPL) offers opportunities for different healthcare professionals to learn from each other. In 2011, the Interprofessional Education Collaborative Experts Panel (CAIPE, 2011), outlined four IPL core competency domains i.e., ethics and values for interprofessional practice, roles, and responsibilities, interprofessional (IP) communication and teams, and teamwork. These four domains illustrate the collaborative role among health professionals to render safe healthcare in clinical areas [2].

In 1990, Miller stated four levels in achieving competency in clinical skills i.e. know, knows how, shows how, and does. 'Does' is the phase of learning related to the highest level of a competency [3]. In clinical training, identifying the gap between 'knowing and doing' is vital to ascertain skills that could be improved. Furthermore, acquiring clinical skills without causing harm to patients is critical in medical education.

Simulation offers an effective means for skills training without causing harm to real patients, closely adhering to level 4 of Miller's pyramid i.e. what a health professional does in a real situation [4]. However, it is merely a technique and not a well-designed technology to replace real-world experiences. Simulation provides guided experiences that imitate significant aspects of the authentic clinical environment in a fully interactive manner [5]. Procedures can be re-enacted using simulation prior to the actual clinical placement of healthcare workers. Corrective measures in striving for a zero error can be implemented in such simulation exercises without causing harm to patients as mentioned in the 'To Err Is Human' report. Nonetheless, simulation provides intensive learning opportunities for acquiring specific skills in high-risk areas, which involves teamwork and communication in collaborative practices [6].

Simulated scenarios have been recommended as a pathway to reduce adverse effects to enhance patient safety [1]. It is applicable across a wide range of medical specialties simulated scenarios engage students emotionally. In fact, high-fidelity simulators can talk, breathe, and move like a real patient [7].

Hospital-acquired infection control (HAIC) has become a patient safety concern; and doctors and nurses need to learn with, from, and about one another to standardize collaboration among the team members. Infections acquired after hospital admission are known as hospital-acquired infections (HAIs). Different infections have different incubation periods so that each occurrence must be evaluated individually to determine the relationship between its occurrence and hospitalization' [8]. These include central line-associated bloodstream infections, catheter-associated urinary tract infections, surgical site infections, and ventilator-associated pneumonia [9].

Adverse events were found among one-third of the hospital inpatients over a one-month period despite the implementation of infection control measures [10]. The incidence of needle stick or sharp injuries among healthcare workers (HCWs) was $23.5 \%$ in a Malaysian government hospital [11]. The adverse impact of HAI i.e. significant excess of treatment costs, and attributable mortality on a huge number of afflicted patients need serious evaluation and remedial action. Another challenge in HAI is obtaining data of occurrences, particularly to confirm that they are directly linked to HAIs episodes [12]. Employing simulation-based education and focused instructions on HAIC is an essential strategy for health professionals.

A review of the literature revealed that there is little data on simulation-based assessment as a medical teaching approach in Malaysia. The recent pandemic outbreak of COVID 19, warranted the crucial need for effective HAIC, which includes mandatory usage of personal protective equipment (PPE) i.e. donning and removing masks and hand hygiene globally. Though the practice of applying the PPE may be burdensome, doctors and nurses must choose the right type of PPE, and be knowledgeable in wearing, removing, and disposal of used PPE. Nevertheless, other measures including good hand hygiene should be prioritized [13].

This study evaluated the effectiveness of intervention using interprofessional simulation scenarios approach on knowledge, attitude, and practice (KAP) in hospitalacquired infection control (IPSSHAIC) among health professionals in a teaching hospital in Klang Valley, Malaysia.

\section{Methods \\ Study design}

An innovative approach employing interprofessional simulation scenarios (IPSS) was used in this quasiexperimental study to improve knowledge, attitude, and practice (KAP) of hospital-acquired infection control (IPSSHAIC) among health professionals. The intervention consisted of (i) a validated questionnaire and (ii) clinical case scenarios. This study was conducted from June 2018 to January 2019 as part of a doctoral program. STROBE reporting guideline was reviewed, and simulation focus concepts were incorporated into this study protocol. i.e. specific objective for each simulated scenario practice and types of simulation used. Blinding techniques were used to address biases [14].

\section{Setting and sample}

This study was conducted in Serdang Hospital, which is an affiliated teaching hospital for University Putra Malaysia in 
Klang Valley, Malaysia. Serdang Hospital is a 620 bedded government-funded multi-specialty setting. Permission was granted by the Clinical Research Centre of Serdang Hospital to collect data. The minimum calculated sample size using Lehr's equation was 18 doctors and 18 nurses for each group [14].

According to Luctkar-Flude et al., [15], mean knowledge of infection control improved as much as $84.95 \%$ (Pre-Test Mean $=5.75 ; \mathrm{SD} 1.09 ; \mathrm{n}=189 ; \quad$ Post-Test Mean $=6.25 ; \mathrm{SD}=0.81 ; \mathrm{n}=106)$ [16]. The tool used to calculate the sample size is retrieved from:

http://www.openepi.com/SampleSize/SSMean.htm.

\section{Recruitment of subjects}

Department heads were approached for permission to participate in this study, subsequently, invitation letters were sent to the respondents. The recruitment was done on a strictly voluntary basis. However, due to constraints in getting respondents because of shift duties and other busy working schedules, purposive sampling was used to recruit doctors and nurses from medical, surgical, pediatric, emergency, and intensive care units. Respondents who were due for maternity or study leave on the days of data collection were excluded from this study.

Health professionals who volunteer to participate were assigned to two groups (i) experimental and (ii) control, based on i.e. willingness to complete the study and attend the follow-up session after three months. Initially, 25 doctors and 26 nurses were recruited through purposive sampling in the experimental group.

\section{Analysis tool}

A validated questionnaire on knowledge, attitude, and practice (KAP) on HAIC adopted from Paudyal, Simkhada, and Bruce (2007) was used [17]. (Refer to Appendix 1: Validation of questionnaire)

The questionnaire has two sections, Sec. 1: Demographic data and Sec. 2: Knowledge, attitude, and practice on hospital-acquired infection control (HAIC).

\section{Section 1: Demographic data}

Researchers gathered demographic data on age, years in practice upon graduation, training attendance in infection control practices, and factors preventing PPE usage.

\section{Section 2: Knowledge, attitude and practice on hospital- acquired infection control \\ (HAIC)}

Upon validation, the final questionnaire consisted of (i) knowledge items (12),

(ii) attitude items (11), and (iii) practice items (14). A total of 37 items were tested. Clinical specialists agreed that all negative items should be recoded.
However, in the final data analysis, two negative items from the attitude domain were discarded due to low corrected item-total correlation and squared multiple correlations. The items are (i) Item number 63: 'Healthcare professionals refusing to provide care for an infectious patient is understandable' and (ii) Item number 64: 'The fear of health professionals of being infected by an infectious patient is understandable' are attitude items. Originally, the Cronbach alpha for the 37 items was 0.67 . Upon deletion of the two negative items, the reliability for the total 35-items questionnaire was inflated to 0.71 .

\section{Scoring}

Knowledge and attitude were rated on a 3-point Likert scale ranging from $1=$ Agree, $0=$ Disagree, or Uncertain). Items related to 'Practice' ranged from $1=$ Always and $0=$ Sometimes or Never. The following are the cumulative scores for each domain: Knowledge (12), Attitude (9), and practice (14).

\section{Interprofessional simulation scenarios (IPSS) on hospital- acquired infection control}

Table 1 describes the specific skills for each scenario and the types of simulation equipment used in the intervention.

\section{Data collection}

The clinical scenarios took place at the Clinical Simulation Centre of Medical Faculty at University Putra Malaysia. Figure 1 illustrates the workflow of the implementation of the overall training program.

The experimental group was briefed on the following and training was provided on three different occasions depending on the availability of subjects;

(i) details on purpose, experimental structure, venue, contents of the intervention, duration, and study significance.

(ii) obtaining consent, and, anonymity and confidentiality assured.

(iii) information regarding 'No risk' in this study.

(iv) the training sessions were offered on three different dates allowing the respondents to choose their availability for the experimental group.

(v) equal opportunity assurance is provided to avoid bias, in this case, equal time to practice.

\section{Experimental group}

Subjects consisted of a doctor and a nurse who practiced on IPSSHAIC. Each scenario was allocated $20 \mathrm{~min}$. Video presentations on IPL and HAIC lectures were presented. Followed by videos on (i) hand hygiene and donning and removing personal protective equipment and 
Table 1 Summary of Simulated Scenarios

\begin{tabular}{|c|c|c|c|}
\hline Simulated scenarios & Objectives & Mannequins/Models & Specific infection control skills \\
\hline $\begin{array}{l}\text { Scenario 1: } \\
\text { Taking blood } \\
\text { specimen }\end{array}$ & $\begin{array}{l}\text { To evaluate the competency in taking blood } \\
\text { specimen }\end{array}$ & $\begin{array}{l}\text { - Human Mannequin } \\
\text { - Venipuncture practice } \\
\text { arm training model }\end{array}$ & $\begin{array}{l}\text { i.Donning and removing double gloves } \\
\text { ii.Disposing soiled swabs into clinical waste } \\
\text { iii.Handling sharps }\end{array}$ \\
\hline $\begin{array}{l}\text { Scenario } 2 \text { : } \\
\text { Bedsore dressing. }\end{array}$ & $\begin{array}{l}\text { To evaluate the competency in performing } \\
\text { bed sore dressing }\end{array}$ & $\begin{array}{l}\text { - Human Mannequin } \\
\text { - Wound care model }\end{array}$ & $\begin{array}{l}\text { iv.Disposing soiled swabs, gauzes and dressing } \\
\text { materials into clinical waste. }\end{array}$ \\
\hline $\begin{array}{l}\text { Scenario } \mathbf{3} \text { : } \\
\text { Collecting sputum for } \\
\text { acid-fast bacilli }\end{array}$ & $\begin{array}{l}\text { To evaluate the competency in collecting } \\
\text { sputum for acid-fast bacilli }\end{array}$ & - Simulated patient & i.Donning and removing N95 mask \\
\hline $\begin{array}{l}\text { Scenario 4: } \\
\text { Intermittent bladder } \\
\text { catheterization }\end{array}$ & $\begin{array}{l}\text { To evaluate the competency in performing } \\
\text { Intermittent Bladder Drainage }\end{array}$ & $\begin{array}{l}\text { - Human Mannequin } \\
\text { - Low-fidelity pelvic model }\end{array}$ & $\begin{array}{l}\text { i.Disposing soiled swabs, gauzes and } \\
\text { catheterization materials into clinical waste }\end{array}$ \\
\hline
\end{tabular}

(ii) IPSSHAICs. The subjects practiced these skills and they were supervised by four co-trainers. They were assessed with structured checklists inclusive of the skills and interprofessional competency domains statements i.e.(i) discussion between doctors and nurses in each group on the scenarios and determine their roles and responsibilities in a respectful manner and, ii. communicate with patients and respect the privacy of patients. Debriefing was given after completion of the scenario practices by the facilitators and principal investigator for twenty minutes. The debriefing was facilitated so that all subjects are aware of good practices in infection control. Verbal review of the case details, feedback with the review of checklists, and a summary of key learning points particularly on the HAIC steps were included in the sessions. The participants answered the questionnaire on HAIC during post-intervention.

After 3-months the subjects attended the practical session on the four IPSSHAICs. The participants rehearsed at each station and were assessed using checklists in a similar method. The completeness of the questionnaires was verified, as well as immediate feedback was provided to participants regarding items on KAP.

\section{Control group}

A briefing session was conducted for the control group with similar information as listed for the experimental group. They were offered a training session on "Recognition Of The Acutely Ill: The ABCDE Approach" as an educational intervention. They were given the option of viewing all learning materials upon completion of the study. The session was conducted by a trainer from the medical faculty of Universiti Putra Malaysia.

\section{Appreciation for participation}

All participants were given a certificate of attendance at the end of the study. Malaysia Medical Council (MMC) has awarded 4 (Continuous Professional Development) points for this training session.

\section{Data analysis}

Statistical analysis was conducted using SPSS version 23.0 (SPSS Inc.) and decision criteria was set at 0.05 alpha level. An independent t-test was employed to determine the significant differences between preintervention experimental and control and; postintervention experimental, and control groups.

\section{Results}

In the control group, 23 doctors and 22 nurses were recruited originally. However, he final data analysis for the experimental group was based on 18 doctors and 18 nurses who completed the post-intervention stage. In the control group, 21 doctors and 19 nurses completed the study. Hence, this study was able to fulfill the required sample size both in the experimental and control groups.

Table 2 shows the demographic information of the participants from both groups in this study. Almost half of the respondents from both groups attended formal training in infection control during their professional development with experimental (58.3\%) and control group (55\%).

Table 3 displays the analysis of items on the Knowledge dimension. The scores of all items increased in the post-experimental group, whereas the scores decreased in the post-control group.

Table 4 displays the attitude dimension scores. The majority of subjects in the post- experimental group solved all items correctly. However, in item number 15; (Patient with an infectious disease should be treated only 


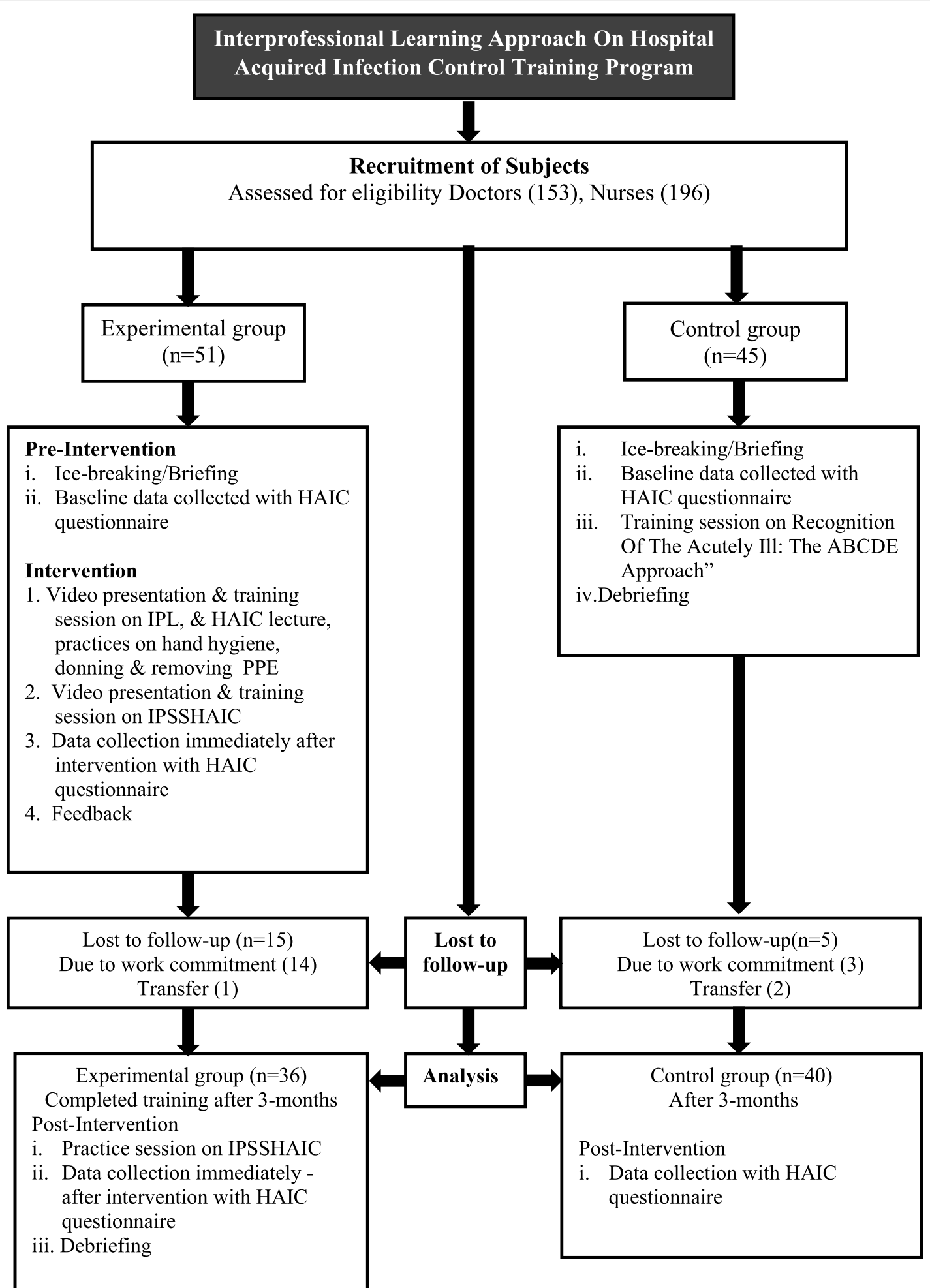

HAIC- Hospital-acquired infection control; IPHAICSS ; Interproessional simulated scenarios on hospital acquired infection control

Fig. 1 Implementation of the interprofessional hospital-acquired infection control training program. HAIC- Hospital-acquired infection control; IPHAICSS ; Interproessional simulated scenarios on hospital acquired infection control. 
Table 2 Demographic data of respondents

\begin{tabular}{|c|c|c|}
\hline & Experimental $(N=36)(n \%)$ & Control $(N=40)(n \%)$ \\
\hline \multicolumn{3}{|l|}{ Age } \\
\hline $25-30$ & $23(63.9)$ & $31(77.5)$ \\
\hline $31-35$ & $9(25)$ & $6(15)$ \\
\hline $36-40$ & $4(11.1)$ & $3(7.5)$ \\
\hline 40 and above & - & - \\
\hline \multicolumn{3}{|l|}{ Gender } \\
\hline Male & $7(19.4)$ & $12(30)$ \\
\hline Female & $29(80.6)$ & $28(70)$ \\
\hline \multicolumn{3}{|l|}{ Job } \\
\hline Doctors & $18(50)$ & $21(52.5)$ \\
\hline Nurses & $18(50)$ & $19(47.5)$ \\
\hline \multicolumn{3}{|l|}{ Highest Qualification } \\
\hline MBBS & $18(100)$ & $21(52.5)$ \\
\hline Diploma in Nursing & 16(44.4) & $18(45)$ \\
\hline Bachelor of Nursing & $2(5.6)$ & $1(2.5)$ \\
\hline \multicolumn{3}{|l|}{ Work Discipline } \\
\hline Surgical & $19(52.8)$ & $10(25)$ \\
\hline Medical & $5(13.9)$ & $10(25)$ \\
\hline Paediatrics & $5(13.9)$ & $2(5)$ \\
\hline Intensive Care Unit & $6(16.7)$ & $4(10)$ \\
\hline Emergency Department & $1(2.8)$ & $14(35)$ \\
\hline \multicolumn{3}{|l|}{ Years in practice } \\
\hline $1-5$ & $22(61.1)$ & $30(75)$ \\
\hline $6-10$ & $9(25)$ & $6(15)$ \\
\hline $11-15$ & $5(13.9)$ & $1(2.5)$ \\
\hline 16 and above & - & $3(7.5)$ \\
\hline \multicolumn{3}{|l|}{ Attended previous training on Infection control } \\
\hline Yes & $21(58.3)$ & $22(55)$ \\
\hline No & $15(41.7)$ & $18(45)$ \\
\hline \multicolumn{3}{|l|}{ Observed wrong practices in infection control } \\
\hline Yes & $21(58.3)$ & $30(75)$ \\
\hline No & $15(41.7)$ & $10(25)$ \\
\hline \multicolumn{3}{|l|}{ Factors preventing PPE usage } \\
\hline Availability & $13(36.1)$ & $11(27.5)$ \\
\hline Inconvenience & $8(22.2)$ & $6(15)$ \\
\hline Too busy & $6(16.7)$ & $13(32.5)$ \\
\hline Availability \& Inconvenience & $3(8.3)$ & $1(2.5)$ \\
\hline Availability \&Too busy & $1(2.8)$ & $2(5)$ \\
\hline Availability, too busy \& Inconvenience & $3(8.3)$ & $3(7.5)$ \\
\hline None of the above & $1(2.8)$ & - \\
\hline Others & $3(8.3)$ & $4(10)$ \\
\hline Have you heard Methicilin resistant Staphylococcus Aureus (MRSA) & $36(100)$ & $40(100)$ \\
\hline
\end{tabular}


Table 3 Knowledge on Hospital-acquired Infection Control

\begin{tabular}{|c|c|c|c|c|c|}
\hline \multirow[t]{2}{*}{ Item } & \multicolumn{3}{|c|}{ Experimental $(N=36)$} & \multicolumn{2}{|c|}{ Control $(N=40)$} \\
\hline & $\begin{array}{l}\text { Pre- } \\
\text { experimenta }\end{array}$ & $\begin{array}{l}\text { Immediate- } \\
\text { experimental }\end{array}$ & $\begin{array}{l}\text { Post- } \\
\text { experimental }\end{array}$ & $\begin{array}{l}\text { Pre- } \\
\text { Control }\end{array}$ & $\begin{array}{l}\text { Post- } \\
\text { Control }\end{array}$ \\
\hline Knowledge & $\begin{array}{l}\text { Correct } \\
\text { n (\%) }\end{array}$ & $\begin{array}{l}\text { Correct } \\
\text { n (\%) }\end{array}$ & $\begin{array}{l}\text { Correct } \\
\text { n (\%) }\end{array}$ & $\begin{array}{l}\text { Correct } \\
\text { n (\%) }\end{array}$ & $\begin{array}{l}\text { Correct } \\
\text { n (\%) }\end{array}$ \\
\hline $\begin{array}{l}\text { 1. Hospital infection is caused by micro-organisms that can be transmitted } \\
\text { between patients }\end{array}$ & $33(91.7)$ & $36(100)$ & $36(100)$ & $35(87.5)$ & 38(95) \\
\hline $\begin{array}{l}\text { 2.Hospital infection can be caused by micro-organism carried on the } \\
\text { hands of healthcare personnel }\end{array}$ & $31(86.1)$ & $36(100)$ & $36(100)$ & $40(100)$ & 40(100) \\
\hline $\begin{array}{l}\text { 3. Hospital infection can be partially prevented by strict compliance to } \\
\text { infection control protocol }\end{array}$ & $27(75)$ & $34(94.4)$ & 35(97.2) & $27(67.5)$ & $32(80)$ \\
\hline 4.Hospital instrument should always be sterilized & $35(97.2)$ & $34(94.4)$ & $36(100)$ & $37(92.5)$ & 36(90) \\
\hline $\begin{array}{l}\text { 5.Invasive devices, such as urinary catheterization, can increase the risk of } \\
\text { hospital infection }\end{array}$ & $31(86.1)$ & $36(100)$ & $36(100)$ & $36(90)$ & 38(95) \\
\hline $\begin{array}{l}\text { 6.A patient in a critical clinical condition increases the risk of hospital } \\
\text { infection }\end{array}$ & $33(91.7)$ & $34(94.4)$ & $36(100)$ & $36(90)$ & $36(90)$ \\
\hline $\begin{array}{l}\text { 7.Inappropriate use of antibiotics can increase the risk of healthcare } \\
\text { associated infection }\end{array}$ & 29(80.6) & $34(94.4)$ & $33(91.7)$ & $30(75)$ & $31(77.5)$ \\
\hline 8.Hands should be washed before and after examining the patient & 35(97.2) & $35(97.2)$ & $36(100)$ & $40(100)$ & 40(100) \\
\hline 9. Hands should be washed after gloves are used & $32(88.9)$ & $36(100)$ & $36(100)$ & 38(95) & $39(97.5)$ \\
\hline 10. Gloves should be changed between patient & $33(91.7)$ & $36(100)$ & $36(100)$ & $33(82.5)$ & 39(97.5) \\
\hline 11.The use of gloves, mask and apron reduces the risk of infection & $36(100)$ & $36(100)$ & $36(100)$ & $39(97.5)$ & 40(100) \\
\hline 12.Hepatitis B can be transmitted by needle stick injury & $27(75)$ & $35(97.2)$ & $35(97.2)$ & $33(82.5)$ & $34(85)$ \\
\hline Maximum & 12 & 12 & 12 & 13 & 12 \\
\hline Minimum & 8 & 10 & 11 & 7 & 17 \\
\hline Mean (SD) & $10.61(1.40)$ & $11.72(0.62)$ & $11.86(0.35)$ & $10.75(1.50)$ & $11.08(1.39)$ \\
\hline
\end{tabular}

Note: SD Standard Deviation

in a specialist centre) least scores were found, $(72.2 \%$ in the post-experimental and $57.5 \%$ in the control group).

Table 5 shows the analysis of practice dimension scores. Scores on post-experimental showed an increase on all the statements but the lowest increase was seen in item 32,(I consume food and beverages at inpatient/ resident care areas) among both groups.

Table 6 shows there was no significant difference in the mean scores between pre-intervention of experimental and control groups mean scores with; $\mathrm{t}(74)=-$ $0.633, p>0.05$. Whereas, there was a significant mean difference between post-intervention of experimental and control groups; t (74) $=-3.654, p=0.001$. Cohen's d effect size $=0.165$, indicating a small effect size according to Cohen's threshold [18]. The IPSSHAIC intervention approach showed improvement in the experimental group.

\section{Discussion}

Developing countries are at a higher risk of healthcareacquired infections, 2 to 20 times more compared to developed countries, and $5-10 \%$ of patients admitted to hospitals in developed countries acquire one or more infections [19]. The shortage of staff was reported as a root cause of several issues i.e. high workload, resulting in some healthcare professionals always occupied with multiple tasks at a time [20]. Besides, that shortage of financial support and resource constraints i.e. availability of gloves and masks are also crucial issues [21]. In this study, the.

highest percentage of wrong practices observed was more significant among the control compared to the experimental group ( $75 \%$ versus, $58.3 \%$ ). In factors preventing using $\mathrm{PPE}$, the constraints of availability of materials was the highest for experimental (36.1\%) and, the control group was too busy option (32.5\%).

Despite the availability of practice guidelines on infection control [8], this study shows non-compliance to HAIC found in this study. Some subjects from both groups failed to comply with practices like gloves must be worn when touching blood, body fluids, excretions, and secretions. Another non-compliance to HAIC practices observed in post-intervention was i.e., on wearing clean washed uniforms daily with $94.4 \%$ in experimental and $77.5 \%$ among the control group. The experimental group in post-intervention also revealed $94.4 \%$ and the 
Table 4 Attitude on Hospital-acquired Infection Control

\begin{tabular}{|c|c|c|c|c|c|}
\hline \multirow[t]{3}{*}{ Attitude } & \multicolumn{3}{|c|}{ Experimental $(N=36)$} & \multicolumn{2}{|c|}{ Control $(N=40)$} \\
\hline & $\begin{array}{l}\text { Pre- } \\
\text { experimental }\end{array}$ & $\begin{array}{l}\text { Immediate- } \\
\text { experimental }\end{array}$ & $\begin{array}{l}\text { Post- } \\
\text { experimental }\end{array}$ & $\begin{array}{l}\text { Pre- } \\
\text { Control }\end{array}$ & $\begin{array}{l}\text { Post- } \\
\text { Control }\end{array}$ \\
\hline & $\begin{array}{l}\text { Agree } \\
\text { n (\%) }\end{array}$ & $\begin{array}{l}\text { Agree } \\
\mathrm{n}(\%)\end{array}$ & $\begin{array}{l}\text { Agree } \\
\text { n (\%) }\end{array}$ & $\begin{array}{l}\text { Agree } \\
\text { n (\%) }\end{array}$ & $\begin{array}{l}\text { Agree } \\
\text { n (\%) }\end{array}$ \\
\hline $\begin{array}{l}\text { 13.Guidelines are necessary for the correct application of disinfection/ } \\
\text { sterilization procedure }\end{array}$ & $36(100)$ & $36(100)$ & $35(97.2)$ & $40(100)$ & $40(100)$ \\
\hline $\begin{array}{l}\text { 14.It is necessary for health professionals to know whether a patient has an } \\
\text { infectious disease }\end{array}$ & 35(97.2) & $36(100)$ & $36(100)$ & 39(97.5) & $40(100)$ \\
\hline $\begin{array}{l}\text { 15.Patient with infectious disease should be treated only in a specialist } \\
\text { centre }\end{array}$ & $25(69.4)$ & $27(75)$ & $26(72.2)$ & $22(55)$ & $23(57.5)$ \\
\hline $\begin{array}{l}\text { 16.Routine hand decontamination (e.g. hand washing) reduces the risk of } \\
\text { infection in patients }\end{array}$ & $36(100)$ & $36(100)$ & $36(100)$ & $40(100)$ & $40(100)$ \\
\hline $\begin{array}{l}\text { 17.Routine hand decontamination (e.g. hand washing) reduces the risk of } \\
\text { infection in healthcare personnel }\end{array}$ & $36(100)$ & $36(100)$ & $36(100)$ & $38(95)$ & $40(100)$ \\
\hline $\begin{array}{l}\text { 18. Hand decontamination between each patient protects both staff and } \\
\text { patients }\end{array}$ & $36(100)$ & $36(100)$ & $36(100)$ & $33(82.5)$ & $40(100)$ \\
\hline $\begin{array}{l}\text { 19.Advise should be given to patient and visitors about prevention and } \\
\text { transmission of hospital-acquired infection }\end{array}$ & $36(100)$ & $36(100)$ & $35(97.2)$ & $39(97.5)$ & $40(100)$ \\
\hline 20.Staff should be aware of aseptic policies & $36(100)$ & $36(100)$ & $36(100)$ & $40(100)$ & $40(100)$ \\
\hline 21. Infection control training is important & $36(100)$ & $36(100)$ & $36(100)$ & $40(100)$ & $40(100)$ \\
\hline Maximum & 9 & 9 & 9 & 9 & 9 \\
\hline Minimum & 8 & 8 & 7 & 7 & 8 \\
\hline Mean (SD) & $8.67(0.48)$ & $8.75(0.44)$ & $8.69(0.53)$ & $8.28(0.75)$ & $8.58(0.50)$ \\
\hline
\end{tabular}

Note: SD Standard Deviation; A Agree; DA Disagree; Uncertain

control group (90\%) in disposing of all the contaminated items into a disposal bag.

In developing training content on HAIC incorporating KAP, a previous study emphasizes the need for both theoretical and practical components [22]. In addition, John et al. (2017) in their study revealed $41 \%$ of medical students received training with no demonstration in handling PPE and, they contaminated their skin in the simulation sessions. improve safe. Clearly, there is a need for formal training of medical students on safe practices in infection control with the implementation of teaching materials that incorporate KAP components [23].

Needlestick injuries (NSIs) are another issue of concern. One Malaysian hospital reported the prevalence of NSIs was statistically significant in orthopedic wards. Findings showed incidences among junior doctors $(31.2 \%)$, specialists $(37.5 \%)$, medical officers (37.5\%), and staff nurses (12.5\%) [24]. When the two groups were evaluated in this study, the experimental group and control group differed following intervention ( $97.2 \%$ vs., $85 \%$ ) in answering item number 12 correctly with regards to knowledge on Hepatitis B can be transmitted by needlestick injury.

There is a need for greater emphasis on strengthening the knowledge of consequences on NSIs. Current observations of health professionals on learning skills in infection control, appear to be coned with little implementation of team approach including all health professional. This study highlights the importance of interventional HAIC training for health professionals. This is supported by the experimental subjects performing better than control subjects who were not provided innovative training in IPL and IC in all three dimensions.

However, both groups scored lower in attitude compared to knowledge and practice dimensions. In fact, the two items removed from data analysis are attitude items. Our study suggests of more training sessions in HAIC may improve health professionals' attitude in infection control as recommended by Xiong et al. (2016). The authors also reported the pre-and post-intervention scores within-group comparisons showed nursing students in the intervention group significantly increased on attitudes $\mathrm{p}<0.01$ after three sessions compared to the control group [25]. Therefore, sustained continuous training sessions on interprofessional infection control improves the attitude dimension of HAIC.

Our recent study on IPL among health professionals revealed the infusion of interprofessional learning training among the health professionals displayed better selfassessments, attitudes and, perceptions towards collaborative practices [26].

The interprofessional learning approach has the possibility of strengthening the collaborative practices on 
Table 5 Practices on Hospital-acquired Infection Control

\begin{tabular}{|c|c|c|c|c|c|}
\hline \multirow[t]{3}{*}{ Practices } & \multicolumn{3}{|l|}{ Experimental } & \multicolumn{2}{|l|}{ Control } \\
\hline & $\begin{array}{l}\text { Pre- } \\
\text { experimental }\end{array}$ & $\begin{array}{l}\text { Immediate- } \\
\text { experimental }\end{array}$ & $\begin{array}{l}\text { Post- } \\
\text { experimental }\end{array}$ & $\begin{array}{l}\text { Pre- } \\
\text { Control }\end{array}$ & $\begin{array}{l}\text { Post- } \\
\text { Control }\end{array}$ \\
\hline & $\begin{array}{l}\text { Practiced } \\
\text { n (\%) }\end{array}$ & $\begin{array}{l}\text { Practiced } \\
\text { n (\%) }\end{array}$ & $\begin{array}{l}\text { Practiced } \\
\text { n (\%) }\end{array}$ & $\begin{array}{l}\text { Practiced } \\
\text { n (\%) }\end{array}$ & $\begin{array}{l}\text { Practiced } \\
\text { n (\%) }\end{array}$ \\
\hline 22.I wash my hand before and after examining a patient & $27(75)$ & $31(86.1)$ & 33(91.7) & $23(57.5)$ & $32(80)$ \\
\hline 23.I dry my hands after hand washing & 30(83.3) & $33(91.7)$ & $32(88.9)$ & $34(85)$ & $37(92.5)$ \\
\hline $\begin{array}{l}\text { 24.I wear gloves whenever there is a possibility of exposure to blood or } \\
\text { other body fluids }\end{array}$ & $32(889)$ & $31(86.1)$ & 35(97.2) & $36(90)$ & $37(92.5)$ \\
\hline 25.I wash my hands after removing disposable gloves & $27(75)$ & $35(97.2)$ & $33(91.7)$ & 28(70) & $32(80)$ \\
\hline $\begin{array}{l}\text { 26. I wear a waterproof apron whenever there is a possibility of blood or } \\
\text { other body fluids splashing on my clothes }\end{array}$ & $24(66.7)$ & $30(83.3)$ & $33(91.7)$ & $29(72.5)$ & $32(80)$ \\
\hline $\begin{array}{l}\text { 27.I wear a mask on my face whenever there is a possibility of blood or } \\
\text { other body fluids splashing }\end{array}$ & 25(69.4) & 34(94.4) & 33(91.7) & $34(85)$ & $35(87.5)$ \\
\hline 28.I wear a clean washed uniform every day & 29(80) & $31(86.1)$ & $34(94.4)$ & $33(82.5)$ & $31(77.5)$ \\
\hline 29.I dispose of all the contaminated items into a disposal bag & 34(94.4) & 35(97.2) & 34(94.4) & $30(75)$ & $36(90)$ \\
\hline 30.I immediately wipe up all spills of blood and any other body fluids & $34(94.4)$ & $35(97.2)$ & $31(86.1)$ & $31(77.5)$ & $33(82.5)$ \\
\hline 31.I cover my broken skin before coming to work & 21(58.3) & $26(72.2)$ & $31(86.1)$ & $29(72.5)$ & $29(72.5)$ \\
\hline 32.I consume food and beverages inpatient/ resident care areas & 28(77.8) & $27(75)$ & $27(75)$ & $25(62.5)$ & $24(60)$ \\
\hline $\begin{array}{l}\text { 34.I protect myself against the blood and body fluids of all patients, } \\
\text { regardless of their diagnosis }\end{array}$ & 23(63.9) & $31(86.1)$ & $32(88.9)$ & $29(72.5)$ & $34(85)$ \\
\hline $\begin{array}{l}\text { 35.I put used needles and other sharp objects into the designated sharp } \\
\text { container }\end{array}$ & $36(100)$ & $36(100)$ & $36(100)$ & $40(100)$ & $40(100)$ \\
\hline 36.I recap used needles & $21(58.3)$ & $27(75)$ & $31(86.1)$ & $26(65)$ & $29(72.5)$ \\
\hline Maximum score & 14 & 14 & 14 & 14 & 14 \\
\hline Minimum score & 6 & 7 & 7 & 5 & 6 \\
\hline Mean (SD) & $10.86(2.52)$ & $12.28(1.98)$ & $12.64(1.85)$ & $10.68(2.74)$ & $11.53(2.48)$ \\
\hline
\end{tabular}

Note: SD Standard deviation

HAIC training and contribute to improving the infection control practices.

\section{Conclusions}

Interprofessional simulation-based scenarios provide strategic opportunities for health professionals to improve safe collaborative practices on knowledge, attitude, and practices (KAP) in HAIC. There was a significant improvement in the experimental group scores following innovative training in HAIC. Training sessions using IPSSHAIC are recommended to be part of the continuous professional development program. Interprofessional simulation scenarios on HAIC have the potential in improving KAP in hospital-acquired infection control and in promoting collaboration among health professionals. This study fills the knowledge gap in the literature on IPL related to HAIC in Malaysia. This study concludes that well-designed interprofessional simulated scenarios can be effective tools in skills training to improve KAP in HAIC and collaboration among health professionals.

\section{Limitations of the study}

Doctors recruited in the experimental group all were house officers, but most nurses were more familiar with HAIC and this was evident in the final results. Obtaining sufficient clinical subjects in each category i.e. years of working experience and equal participation from each discipline was challenging. Subjects also expressed logistic limitations as the hospital is located at different premises from the faculty clinical school. Moreover, the subjects were recruited only on a voluntary basis. The high dropout rate though fulfills the sample size, however limits the study to a smaller analyzable sample. This fact is compounded by the purposive sampling

Table 6 Knowledge, Attitude and Practice in Hospital-Acquired Infection Control among health professionals

\begin{tabular}{|c|c|c|c|c|c|}
\hline Group & Mean Score \pm SDExperimental & Mean Score \pm SDControl & $\mathbf{t}$ & df & $p$-value \\
\hline Pre-intervention of experimentaland control groups & $1.16( \pm 0.12)$ & $1.18( \pm 0.11)$ & -0.633 & 74 & 0.529 \\
\hline Post-interventionof experimentaland control groups & $1.06( \pm 0.59)$ & $1.13( \pm 0.10)$ & -3.428 & 74 & 0.001 \\
\hline
\end{tabular}


techniques applied in the study though randomization was initiated earlier. Ideally, evaluation should incorporate a variety of methods.

A mixed-mode with the qualitative study would provide in-depth knowledge on many dimensions not possible with quantitative studies of this nature. However, this is recommended for future studies. There is a need to improve review exiting protocols on IPL when new health professionals join the team. The HAIC includes a wide range of practices in hospitals and it was not possible to cover all aspects of HAICPs in one paper. Therefore, only selected key issues were examined.

\section{Supplementary Information}

The online version contains supplementary material available at https://doi. org/10.1186/s12909-021-02907-1.

\section{Additional file 1.}

\section{Acknowledgements}

We would like to thank the Director General of Health Malaysia for his permission to publish this article.

\section{Authors' information (optional)}

Correspondence to ANS.

\section{Authors' contributions}

ST, NS, RAM, and ANS contributed to the study conception and design, interpretation of data, and critical revision of the manuscript. ST was involved in the literature review, data collection, data analysis, and manuscript drafting. JK was involved in the study design and critical revision of the manuscript. RS was involved in data analysis and critical revision of the manuscript. HK was involved in data analysis and interpretation. All authors read the final manuscript.

\section{Funding}

Not applicable.

\section{Availability of data and materials}

The data and materials are not available as this study's findings are based on baseline data collected in a doctoral project and need to be submitted to Universiti Putra Malaysia. However, the corresponding author can be contacted at reasonable request.

\section{Declarations}

\section{Ethics approval and consent to participate}

Ethical approval for this study was obtained from the Medical Research and Ethics Committee (MREC), Ministry of Health Malaysia." The registration number is NMRR-16-2852-32986(IIR); Protocol Number: 32986. Informed consent was obtained from participants upon agreeing to participate and confidentially was assured. They were informed there is no risk involved in this study. All methods were carried out in accordance with relevant guidelines and regulations.

\section{Consent for publication}

Consent for publication was obtained from National Institutes of Health, Malaysia.

\section{Competing interests}

All authors report no financial and non-financial competing interest. The authors alone are responsible for the content and writing of this article.

\section{Author details}

'Department of Medical Microbiology, Faculty of Medicine and Health

Sciences, Universiti Putra Malaysia, Serdang, Selangor, Malaysia. ${ }^{2}$ International
Medical College, Subang Jaya, Malaysia. ${ }^{3}$ Department of Obstetrics and Gynaecology, Clinical Sciences, International Medical University, Seremban, Negeri Sembilan, Malaysia. ${ }^{4}$ Department of Community Health, Faculty of Medicine \& Health Sciences, Universiti Putra Malaysia, Serdang, Selangor, Malaysia. ${ }^{5}$ Department of Psychology, International Medical University, Bukit Jalil, Kuala Lumpur, Malaysia. ${ }^{6}$ Department of Nursing, Faculty of Medicine, Universiti Kebangsaan Malaysia, Bangi, Malaysia. ${ }^{7}$ Research Institute of Aging(MyAgeing), Universiti Putra Malaysia, Serdang, Selangor, Malaysia.

Received: 1 January 2021 Accepted: 25 August 2021

Published online: 09 September 2021

\section{References}

1. Institute of Medicine (US) Committee on Quality of Health Care in America, Kohn LT, Corrigan JM, Donaldson MS, eds. To Err is Human: Building a Safer Health System. Washington (DC): National Academies Press (US); 2000.

2. IPEC. Core Competencies for Interprofessional Collaborative Practice. 2011.

3. Miller GE. The assessment of clinical skills/competence/performance. Acad Med. 1990 Sep;65(9 Suppl): S63-7. https://doi.org/10.1097/00001888-1 99009000-00045. PMID: 2400509.

4. Flanagan B, Nestel D, Joseph M. Making patient safety the focus: crisis resourcemanagement in the undergraduate curriculum. Med Educ. 2004; 38(1):56-66. https://doi.org/10.1111/j.1365-2923.2004.01701.x.

5. Gaba DM. The future vision of simulation in healthcare. Simul Healthc. 2007; 2(2):126-135. doi:https://doi.org/10.1097/01.SIH.0000258411.38212.32

6. Phrampus PE. Simulation and Integration into Patient Safety Systems. Simul Healthc. 2018;13(4):225-226. doi:https://doi.org/10.1097/SIH. 0000000000000332

7. Khan K, Pattison T, Sherwood M. Simulation in medical education. Med Teach. 2011;33(1):1-3. doi:https://doi.org/10.3109/0142159X.2010.519412

8. Ministry of Health Malaysia. Policies And Procedures On Infection Control, https://www.moh.gov.my/moh/images/gallery/Polisi/infection_control.pdf; 2010. [accessed 14 October 2020].

9. Rai V, Yuet-Meng C, Rosenthal VD, Hasan MS. et al. Device-associated infection and mortality rates, bacterial resistance, and length of stay in hospitals of Malaysia: International Nosocomial Infection Control Consortium (INICC)'s findings. Canadian Journal of Infection Control. 2016;31(2). https:// www.researchgate.net/publication/315114757_Device-associated_ infection_and_mortality_rates_bacterial_resistance_and_length_of_stay_in_ hospitals_of_Malaysia_International_Nosocomial_Infection

10. Classen DC, Resar R, Griffin F, et al. 'Global trigger tool' shows that adverse events in hospitals may be ten times greater than previously measured [published correction appears in Health Aff (Millwood). 2011 Jun;30(6):1217]. Health Aff (Millwood). 2011;30(4):581-9. https://doi.org/10.1377/hlthaff.2011. 0190

11. Rampal L, Zakaria R, Leong J, Zain A. Needle stick and sharp injuries and factors associated among healthcare workers in a Malaysian hospital. European Journal of Social Sciences. 2010;13(3):354-362.

12. World Health Organization. Report on the burden of endemic healthcareassociated infection worldwide. https://apps.who.int/iris/handle/10665/8013 5; (2011) [Accessed 14 Oct 2020].

13. Ambigapathy S, Rajahram GS, Shamsudin UK, et al. How should front-line general practitioners use personal protective equipment (PPE)? Malays Fam Physician. 2020;15(1):2-5.

14. Cheng A, Kessler D, Mackinnon R, et al. Reporting Guidelines for Health Care Simulation Research: Extensions to the CONSORT and STROBE Statements. Simul Healthc. 2016;11(4):238-248. doi:https://doi.org/10.1097/SIH. 0000000000000150

15. Luctkar-Flude M, Hopkins-Rosseel D, Jones-Hiscock C, Pulling C, Gauthier J, Knapp A, et al. Interprofessional infection control education using standardized patients for nursing, medical and physiotherapy students. J Interprofessional Educ Pract. 2016;2:25-31. https://doi.org/10.1016/j.xjep.201 6.03.004.

16. Lehr R. Sixteen S-squared over D-squared: a relation for crude sample size estimates. Stat Med. 1992;11(8):1099-1102.https://doi.org/10.1002/sim.4 780110811.

17. Paudyal P, Simkhada P, Bruce J. Infection control knowledge, attitude, and practice among Nepalese health care workers. Am J Infect Control. 2008; 36(8):595-7. https://doi.org/10.1016/j.ajic.2007.10.026.

18. Statistical Cohen J, Analysis Power. Current Directions in Psychological Science. 1992;1 (3):98-101. https://doi.org/10.1111/1467-8721.ep10768783. 
19. World Health Organization. Infection prevention and control in healthcare: time for collaborative action. Available from: https:/apps.who.int/iris/ha ndle/10665/122923; (2010b) [Accessed 14 Oct 2020].

20. Azura Abdul Halain, Kim Lam Soh, Airini Ibrahim, Salimah Japar, Swee Leong Ong, Abdurrahman Muhammad Sani, Kim Geok Soh. Nursing Workload in Relation to Nosocomial Infection in Public Hospital Intensive Care Unit, Malaysia. Research J. Pharm. and Tech 2018; 11(9): 3892-3896. https://doi.org/10.5958/0974-360X.2018.00713.

21. Joshi SC, Diwan V, Joshi R, et al. "How Can the Patients Remain Safe, If We Are Not Safe and Protected from the Infections"? A Qualitative Exploration among Health-Care Workers about Challenges of Maintaining Hospital Cleanliness in a Resource Limited Tertiary Setting in Rural India. Int J Environ Res Public Health. 2018;15(9):1942. Published 2018 Sep 6. https://doi.org/1 0.3390/ijerph15091942

22. Choi JS, Kim KM. Factors influencing nursing students' intention to comply with infection control practices. Am J Infect Control. 2018;46(6):717-719. doi:https://doi.org/10.1016/.ajic.2017.12.010

23. John A, Tomas ME, Hari A, Wilson BM, Donskey CJ. Do medical students receive training in correct use of personal protective equipment? Med Educ Online. 2017;22(1):1264125. doi:https://doi.org/10.1080/10872981.2017.12 64125

24. Bhardwaj A, Sivapathasundaram N, Yusof M, Minghat A, Swe K, Sinha N. The Prevalence of Accidental Needle Stick Injury and their Reporting among Healthcare Workers in Orthopaedic Wards in General Hospital Melaka, Malaysia. Malays Orthop J. 2014;8(2):6-13. doi:https://doi.org/10.5704/MOJ.14 07.009

25. Xiong $\mathrm{P}$, Zhang J, Wang $X$, Wu TL, Hall BJ. Effects of a mixed media education intervention program on increasing knowledge, attitude, and compliance with standard precautions among nursing students: A randomized controlled trial. Am J Infect Control. 2017;45(4):389-395. doi: https://doi.org/10.1016/j.ajic.2016.11.006

26. Thangarajoo S, Rosliza AM, Nalliah S, et al. Self-assessment, attitude and perception of interprofessional learning in hospital acquired infection control practices among health professionals in Klang Valley, Malaysia. BMC Med Educ. 2021:21(1):243. Published 2021 Apr 26. https://doi.org/10.1186/ s12909-021-02610-1

\section{Publisher's Note}

Springer Nature remains neutral with regard to jurisdictional claims in published maps and institutional affiliations.

Ready to submit your research? Choose BMC and benefit from:

- fast, convenient online submission

- thorough peer review by experienced researchers in your field

- rapid publication on acceptance

- support for research data, including large and complex data types

- gold Open Access which fosters wider collaboration and increased citations

- maximum visibility for your research: over $100 \mathrm{M}$ website views per year

At $\mathrm{BMC}$, research is always in progress.

Learn more biomedcentral.com/submissions 